CIRR XXI (72) 2015, 47-82

ISSN 1848-5782

UDC 327(4-6EU)

DOI 10.1515/cirr-2015-0002

\title{
The Number and Geographical Scope of the EU Foreign Policy Initiatives of Small Member States: Does „smallness" matter?
}

Đana Luša, Petar Kurečić

\section{Abstract}

Due to the complex voting and decision-making mechanisms of the EU, the size-factor has long been present within EU studies as a relevant and significant variable in explaining member states' activism. Despite the aim of small states to achieve equal representation, there is a huge discrepancy between the power of big and small states within the EU. Therefore, the expected behavior of small states is different from that of the big ones. However, there are also significant differences in foreign policy activism within the group of small EU states and those are analysed in this article. In order to differentiate small states' activism within EU foreign policy, the article explores the correlation between the scope and number of small states' leadership initiatives in EU foreign policy and different quantitative criteria used to define these small states (population, total GDP, GDP per capita).

\section{KEY WORDS:}

small states, quantitative criteria, EU foreign policy, activism, foreign policy initiatives 


\section{Introduction}

Existing studies on small states suggest that one rule is a permanent feature: there are as many different criteria and thus classifications of small states as there are authors.' Most EU studies use population, territory and GDP as the main criteria when defining a state. Panke (2010: 799), for example, analyzed the allocation of votes in the Council of the EU (Council of Ministers), where states with fewer votes than the EU-average were defined as small. This approach is more reliable as it comprises the size and population of the member states at the same time. However, there are more subjective definitions of small states, singling them out as the weaker parties in an asymmetric relationship, unable to change its nature on their own. As a consequence, all EU member states are considered small, except for France, Germany and the UK, which makes this approach too selective and oversimplified (Mouritzen, Wivel 2005: 4; Howard Grøn, Wivel 2011: 524).

Due to the complex voting and decision-making mechanisms of the EU, the size-factor has long been present within EU studies as a relevant and significant variable in explaining member states' activism. Despite the fact that the aim of the different institutional mechanisms, such as the voting system in the Council of the EU (Council of Ministers), or the distribution of seats in the European Parliament, is to achieve equal representation, many claim that there is a huge discrepancy between the power of big and small states (Czina 2014: 7). Namely, big states have more voting power in the Council of the EU under the majority voting provision, which now applies to most areas of policy making. They can also more credibly exercise a veto in cases where unanimity is required and make side-deals outside the formal decision-making process (see Keating, McEwen and Harvey 2014).

Although there are various criticisms of studies of small states, which notably focus on objective (quantitative) characteristics of states, instead of looking at more subjective circumstances (such as political capacities and constraints), this article uses a quantitative approach for explaining small states' leading initiatives in the realm of EU foreign policy (Czina

1 For more information on classification of small states see: Luša, Kurečić 2014: 266-280. 
2014:8). When quantitative criteria are used in defining small states, it is most likely that at least one of these three main characteristics of any particular state are considered: population, area and GDP.

Thorhallsson and Wivel argue that both objective factors (the material, quantifiable aspects of power) and subjective factors (the perception of power) have to be examined to determine the influence of a state (Thorhallsson, Wivel 2006: 654), which is measured by comparing member states' preferences to what they have achieved in a certain policy area (Czina, 2014:6-7). However, we decided to analyze the correlation between the scope and intensity of small states'leadership initiatives ${ }^{2}$ (or activism) ${ }^{3}$ in the EU foreign policy and different quantitative criteria (population, total GDP, GDP per capita), with the aim of explaining the differences among small EU member states. This article argues that quantitative criteria are still a relevant and significant variable in explaining the behavior of small states in the EU. Small states are likely to possess characteristics which are different from those of big states; therefore it can be expected that their behavior will be different as well (Thorhallsson 2011: 1). However, there are huge discrepancies even within the group of small states, which are also analyzed in this article. Namely, older small member states are generally believed to be more active and effective in the EU than the new ones, because of their experience, influence, networks and expertize. Therefore, the starting question is: what factors determine the activism of small states within the EU policy framework (Czina 2014: 3)? We claim that in terms of EU foreign policy initiatives population, total GDP and GDP per capita are very important defining features.

Data about the total population (2013), ${ }^{4}$ GDP and GDP per capita (2013) ${ }^{5}$

2 A foreign policy initiative is described as an activity of states attempting to further their interests and increase their influence on the international stage. This term does not incorporate the result of power or the effectiveness of such action, but instead focuses on the attempt made by the state. This attempt is characterized by a large amount of substantial and autonomous activity initiated by the state or in conjunction with other states in events occurring abroad (Scheldrup 2014: 16).

3 Foreign policy activism can be defined as a policy or strategy aimed at creating, preserving or changing a given international order according to the interests and values of the policy-maker. Holm (2002) has suggested that the concept of activism has three dimensions: (1) the degree of initiative, (2) the strategically based use of available means in a continual pursuit of goals and (3) the resources set aside and mobilized in a prioritized fashion. An active policy also involves taking risks.

4 The population of the EU and its member states (estimate on January 1, 2014): http://epp.eurostat.ec.europa.eu/tgm/ table.do? tab=table\&init=1 \&language $=e n \& p c o d e=t p s 00001$ \&plugin=1 (accessed 28 May 2014)

5 http://ec.europa.eu/eurostat/statistics-explained/index.php/

http://ec.europa.eu/eurostat/statistics-explained/index.php/GDP_per_capita,_consumption_per_capita_and_ price_level_indices\#Further_Eurostat_information (accessed 29 September 2014) 
were discussed in order to determine which states would be included in the analysis. According to ECFR Scorecard reports for 2011, 2012 and 2013, the number of foreign policy initiatives in which some state had a leading role, were taken into account with the aim of analyzing the relation between the size of the EU member states and the level of their activism within the EU foreign policy arena. The Scorecard provides annual assessments of the EU institutions' performance on 80 policy areas around six key themes: China, Russia, the United States, Wider Europe and Crisis Management and Multilateral issues. However, the Scorecard's methodology is faced with inevitable simplifications, as well as with the problem of the definition of success in foreign policy. Member states were identified as "leaders" when they either took the initiative in a constructive way or acted in an exemplary way, which involved a political judgment and should not be considered definitive. In addition, according to the authors of the Scorecard, the meaning of being a "leader" varies in each case. Namely, a small state may need to spend great energy on blocking a policy development or proposal that it disagrees with, which does not show up on the Scorecard, and may result in a false picture of overall activity and influence. Furthermore, the causal link between one specific set of European policies on the one hand and results on the other is problematic. ${ }^{6}$ Having this in mind, one needs to point at the limitations of the "fuzzy" quantity presented by the Scorecard as well as the conclusions reached in this research that are based upon it. However, the Scorecard offers the only quantitative analysis of EU foreign policy and the activism of each member state.

Twelve EU member states, with a population below six million, were analyzed as the primary target group. The next eight EU member states, with a population between six and 12 million (more specifically between 7.3 in the case of Bulgaria and 11.3 million in the case of Greece), were studied as a secondary group, in order to compare the results between the two groups and to examine whether population size, as a key factor, directly influences the number and scope of small states' foreign policy activities, or if other factors should be taken into account. Therefore, the number of the leadership positions divided among twenty EU states with a population below 12 million, based on the ECFR Scorecard for 201 1, 2012, and 2013 was analyzed. Data related to different leadership initiatives (so-

6 http://www.ecfr.eu/scorecard/2014/extras/methodology 
called "leaders" according to the ECFR Scorecard) were compared to population, total GDP and GDP per capita metrics for the aforementioned states. The number, as well as the character and geographical scope of foreign policy initiatives in which those states were "leaders" were analyzed in order to identify possible regularities that would support the following three hypotheses:

$\mathrm{H1}$ : When it comes to small EU member states, the size of the state, measured by its population, affects its foreign policy activism.

H2: The level of economic development (measured by total GDP and GDP per capita) as well as the current economic difficulties (recession, high unemployment etc.) affect the intensity of foreign policy activism of small EU member states. Higher GDP per capita and better economic performance mean a higher level of foreign policy activism (and vice versa).

H3: Small EU states have a narrow foreign policy scope, primarily focused on their surroundings. They are either not interested or not capable (sometimes both) in becoming leaders in resolving issues that do not affect them directly.

\section{Foreign Policy Making in the EU}

Since the Maastricht Treaty the EU's external policies have been formulated and managed under one of two separate institutional processes: 1) the Common Foreign and Security Policy (CFSP), which includes Common Security and Defence Policy and is intergovernmental in nature (acting on the basis of unanimous agreement in the European Council and the Council of the EU) and 2) external policies in areas such as trade, foreign aid and EU enlargement, which are shaped and executed under a supranational or "community" decision-making process involving all three main EU institutions. However, the Lisbon Treaty set out to remedy the following three weaknesses identified regarding the EU foreign policy 
process: the difficulty of achieving political agreement among 28 member states, insufficient institutional coordination and coherence (manifested in intergovernmental and supranational strands of external policy not being linked in a meaningful way), and the shifting priorities of previous institutional arrangements (rotating six-month national presidencies in external affairs). Therefore, a new position of High Representative of the Union for Foreign Affairs and Security Policy was created to allow the performance of external policy duties by combining the roles of the previous High Representative and External Affairs Commissioner, as well as that of the Presidency. This position coordinates the intergovernmental and "community" dimensions of EU external policy, thus presenting an institutional bridge that couples the interests of small and big member states. In order to support the work of the High Representative in coordinating and implementing EU foreign policy, a new EU diplomatic corps, the European External Action Service (EEAS) was created (an operational center connected to a worldwide EU diplomatic service in external countries), as well as the function of a new permanent president of the European Council serving a once-renewable, two-and-ahalf-year term (Mix 2013:2 ). Small states prefer the "community method" of decision-making, as stipulated in the treaties, which involves the European Commission taking the initiative, while the Council of the European Union (representing the member states) and the European Parliament making the final decision. With the enlargement rounds of 2004, 2007 and 2013, which encompassed 13 new members (small states currently present a majority within the EU), the "community method" was preserved, even if it was weakened. On the other side, the rise of the European Council has undermined the "community method" and enhanced the power of big states (see Keating, McEwen, and Harvey 2014).

The EU has created institutional structures and instruments to develop and implement a CFSP and the member states have integrated their foreign policies to a remarkable degree on many issues. Therefore, "when the EU speaks as one, it can speak with a strong voice". However, challenges remain on reaching consensus on CFSP, having in mind the different national positions, capacities, resources and coalition potentials of member states. At the same time, one needs to acknowledge the existence of a gravitational pull towards the institutional shield the EU provides for. Namely, although several big EU states remain international powers in their own right, analysts assert that, absent their membership in a strong and unified EU, 
these states could someday find themselves being global middleweights. Similarly, although the smallest member states occasionally fear that their voices are being drowned out within the EU, they are arguably even less likely to be heard from outside the EU (Mix 2013: 8-9).

The fact that the economic, political, military and diplomatic capacity of a member state plays an important role in determining its influence in EU bodies is a reflection of the current international system, which remains based on power relationships. The process of foreign policy making in the EU is currently based on an unwritten bargain between big and small states. Only big states have the capacity to assess the situation and to suggest a policy line on many foreign policy developments. The big states' informal lead is tolerated by the other members since the system offers them a greater influence than they would have otherwise. Therefore, small states tolerate the fact that many important foreign policy discussions in the EU are preceded by informal consultation involving only the big states (Lehne 2012:3).

In the absence of clear rules, this relationship remains inherently unstable. There is constant concern among the small states that the informal steering role of the big states might turn hegemonic and that they will increasingly be confronted with pre-made decisions. The adoption of the Lisbon Treaty partly strengthened the leadership role of the big members, while its entry into force has affected the balance between big states' leadership and the need for inclusiveness. In some ways, it strengthens the leadership role of the big members, as the European Council president and the High Representative find it more difficult to resist their positions. On the other hand, in terms of inclusiveness, the EEAS could gradually take over some of the steering functions that are currently informally assumed by the big member states (Lehne 2012: 4). As small states' limited resources do not allow them to efficiently make lobbying efforts with every rotating Presidency, developing stable long-term relationships with the EEAS staff suits their needs better. Since the EEAS drafts the policy proposals, the small new member states can seek to influence the decision-making already in its formulation stage, through contacting the EEAS and providing their specific concerns. The evidence shows that small new member states, if their preferences and interests are well defined, can successfully inject their policy ideas through these new institutions, which is also demonstrated by our research (Pastore 2013: 78). 


\section{S Small states' strategies and influence in the EU's Foreign Policy Making}

Most states in the international arena are not "powerful" and yet some of them still conduct relatively successful foreign policy. Lacking the resources (e.g. territory, natural resources, population, military or great history) they can set themselves only small or moderate goals. The possession of abundant material resources, i.e. power, in the traditional or the sense perceived by realism, does not automatically convert into successful foreign policy. Namely, success in foreign policy depends on both its efficiency and legitimacy, which are interdependent (Rolenc 2013:1-2), and is not measured per se, but rather serves as a function of difficulty, possibilities or performance, given the underlying difficulty of issues and progress in meeting the set objectives.

We claim that quantitative criteria (population, total GDP and GDP per capita) are significant and inevitable in understanding the behavior of states. Changes in international relations have given small states new avenues for influencing other states and taking on a foreign policy profile above their diminutive stature. However, there is substantial variation among these states in the extent to which they have pursued an outsized foreign policy. Why have some small states demonstrated a higher level of foreign policy activism in the EU than others? Which criteria mostly influence small states' initiatives and leadership in EU foreign policy making (Scheldrup 2014: 2)?

There are different foreign policy strategies used by small states in international relations. Vital (1967) identified the choice of three broad policies: a passive strategy of renunciation, an active strategy designed to alter the external environment in their favor, or a defensive strategy attempting to preserve the status quo. ${ }^{7}$ Researchers have mainly claimed that the first and ultimate foreign policy goal of small states during the Cold War was to achieve defensive power, i.e. the ability to resist the offensive power of other units (Mouritzen 1998: 44), while in reality many of them have been able to exercise active foreign policy in some fields 
of international cooperation(Goetschel 2000: 6). The end of the Cold War signalized a new impetus for small states to become more active and to start their leadership role within international organizations, which provided them with the necessary institutional and policy framework. Consequently, small states have participated in the international system in ways unaccounted for in previous literature. Braveboy-Wagner (2010: 407) argues that small states will generally focus on smaller foreign policy circles, for example their regional neighborhood. "Even very small states can exercise power within limited domains as long as they possess certain capabilities and are ready to seize available opportunities" (BraveboyWagner 2010: 407).

Since small states generally have fewer resources 9 than big states, they are obliged to choose fewer fields of cooperation, in which they try to turn their existing resources and capabilities to their advantage (Šabič 2002: 6). A small state pursuing an active foreign policy strategy has to lean on the advantages as they arise from security geography (Benko 1992: 6). Benko defines geography and history as determinants of the internal environment of a state's foreign policy (1997: 233), while the external environment of foreign policy is mainly determined by features of a certain international system, including the role of international organizations. This environment also has geographical, economic, cultural and other determinants, but they are defined as "constituting an external environment of foreign policy" because they are "not easily susceptible to change and not part of the political process, which generates decisions" (Hill 2003:186). The internal (domestic) and external environments of foreign policy are not separated, but are in interaction (Bojinovic 2005:12).

Besides the definitional issue related to the concept of small states, the bulk of research is focused on what has become conventional wisdom in explaining small state behavior, namely the systemic and state level of analysis. Many findings point out that under specific conditions small states may yield substantial influence in EU foreign policy. For example, Lindell and Persson (1986: 80-85) identified three systemic factors, which are particularly relevant for the study of small states' activism in EU foreign policy: the

8 The main exceptions are those states that have high GDP (because of a very high GDP per capita), for example Sweden.

9 Understood as political capital as well as tangible resources such as money, troops and training personnel. 
structure of the system, the state of the system and the prevailing norms within a given system. The structure of the system is defined as the extent to which a system is hegemonic or hierarchical, or whether it is characterized by a balance of power or not. In the context of the EU, this differentiation could be seen in terms of institutionalization: whether the policy area under investigation is densely institutionalized or whether it remains highly hierarchical (Nasra 2010: 2). Namely, the degree of institutionalization is positively correlated with possibilities for small states' activism, taking into account their lack of capacities and resources to participate in behind the scenes arrangements and deals, mostly agreed by big states. A second systemic factor is the state of the system, which refers to the degree of tension and conflict between the dominating actors. It is assumed that increased tension between dominating actors leads to more possibilities for small states to exert influence, acting for example as mediators. Prevailing norms are the last systemic factor and are generally associated with a constructivist reading, stressing the importance of informal rules, roles and identities. There are certain policy areas in which small member states proved their role as norm entrepreneurs (Finland and the EU's Northern Dimension, Sweden and Conflict Prevention, the Scandinavian countries and European Security and Defence Policy) (see Nasra 2010: 2-3).

According to Nasra, the success of a small state's behavior depends foremost on "the existence of a window of opportunity", which is mostly created by the preferences of big member states, structure of the policy process, as well as the existence of generally accepted norms of behavior. Nevertheless, a small state still needs to "pursue active national strategies in order to valorize the existence of a window of opportunity" (Nasra 2010: 14). This is the area in which there are huge differences between small EU member states. Namely, while some are proactive and innovative in their foreign policy behavior, others are reactive by using buck passing and bandwagoning strategies (by leaving leading roles to other states, as well as by exploiting other states' initiatives). The notion of a state "should be seen in relation to the power it exercises rather than the power it possesses" (Mouritzen, Wivel 2005: 4). Whereas being small is a characteristic of states at a systemic level, the difference between small and big can be significantly reduced when it comes to a state's actions and strategies (state level) ${ }^{10}$ (Nasra 2010: 14). The article focuses on determining the 
correlation between the levels of foreign policy activities (in this case the number of foreign policy initiatives in which small states were leaders ${ }^{11}$ ) influenced by developments in the international community (systemic level) and quantitative criteria (material power they possess expressed through their GDP) as state characteristics.

\section{Analysis of small member states' activism in EU foreign policy}

Table 1. GDP (in millions of Euros), GDP per capita (in Euros) and population (in thousands) of the twenty analyzed EU member states: ${ }^{12}$

\begin{tabular}{|l|l|l|l|}
\hline & $\begin{array}{l}\text { GDP in millions of } \\
\text { Euros }\end{array}$ & $\begin{array}{l}\text { GDP per capita in } \\
\text { Euros }\end{array}$ & Population in thousands \\
\hline Malta & 7.200 & 17.100 & 400 \\
\hline Cyprus & 16.500 & 19.000 & 900 \\
\hline Estonia & 18.400 & 13.800 & 1.300 \\
\hline Latvia & 23.400 & 11.600 & 2.000 \\
\hline Lithuania & 34.600 & 11.700 & 3.000 \\
\hline Slovenia & 35.300 & 17.100 & 2.100 \\
\hline Bulgaria & 39.900 & 5.500 & 7.300 \\
\hline Croatia & 43.100 & 10.100 & 4.300 \\
\hline Luxembourg & 45.500 & 83.400 & 500 \\
\hline Slovakia & 72.100 & 13.300 & 5.400 \\
\hline Hungary & 97.900 & 9.900 & 9.900 \\
\hline Czech Republic & 149.500 & 14.200 & 10.500 \\
\hline Ireland & 164.100 & 35.600 & 4.600 \\
\hline Portugal & 165.700 & 15.800 & 10.500 \\
\hline
\end{tabular}

deliberate (Nasra 2010). Analysis of these variables could cast a different light on our findings (most notably, whether a state is pro-EU or EU-skeptical, and whether it specifically believes or disbelieves in the EU's effectiveness and legitimacy as a diplomatic and security actor). However, this kind of analysis surpasses the scope of this article.

11 It is possible for member states to "lead" either directly (in other words by forcing or persuading member states to take action) or indirectly ("leading by example").http://www.ecfr.eu/scorecard/2014/extras/methodology.

12 Population of the EU and its member states (estimate on January 1, 2014):http://epp.eurostat.ec.europa.eu/tgm/ table $\cdot$ do? $t a b=$ table\&init=1 \&language $=e n \& p c o d e=t p s 00001 \&$ plugin=1 (accessed 28 May 2014). http://ec.europa.eu/eurostat/statistics-explained/index.php/ 


\begin{tabular}{|l|l|l|l|l|}
\hline Greece & 182.100 & 17.400 & 11.300 \\
\hline & $\begin{array}{l}\text { GDP in millions of } \\
\text { Euros }\end{array}$ & $\begin{array}{l}\text { GDP per capita in } \\
\text { Euros }\end{array}$ & Population in thousands \\
\cline { 2 - 5 } & 193.400 & 35.600 & 5.400 \\
\hline \multirow{2}{*}{} & Finland & 249.100 & 44.400 & 5.600 \\
\cline { 2 - 5 } \\
\cline { 2 - 5 } & Denmark & 313.000 & 37.000 & 8.500 \\
\cline { 2 - 5 } & Austria & 382.700 & 34.500 & 11.200 \\
\cline { 2 - 5 } & Belgium & 420.800 & 43.800 & 9.600 \\
\cline { 2 - 5 } & Sweden & &
\end{tabular}

Figure 1. GDP (in millions of Euros), GDP per capita (in Euros) and population (in thousands) of the twenty analysed EU member states

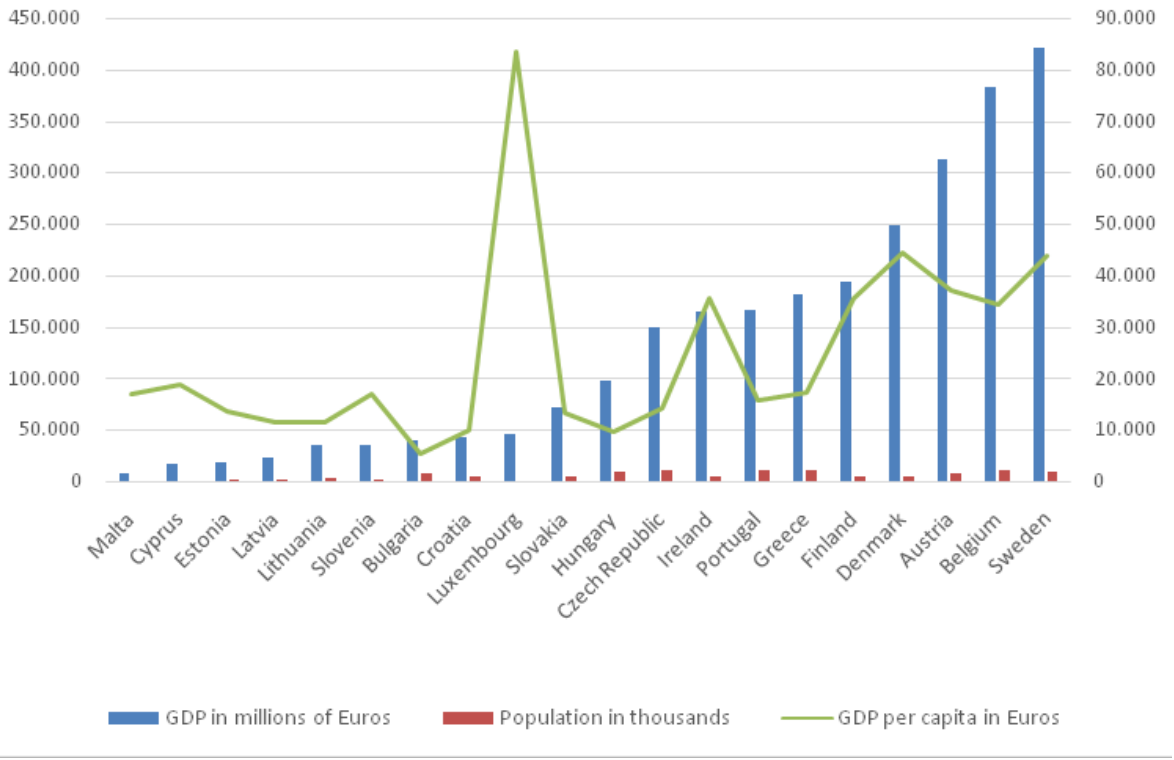


Table 2. The twelve smallest (with population below six million) EU member states: "leaders" from the ECFR Scorecard, 2011-2013", by areas and issues:

\section{1}

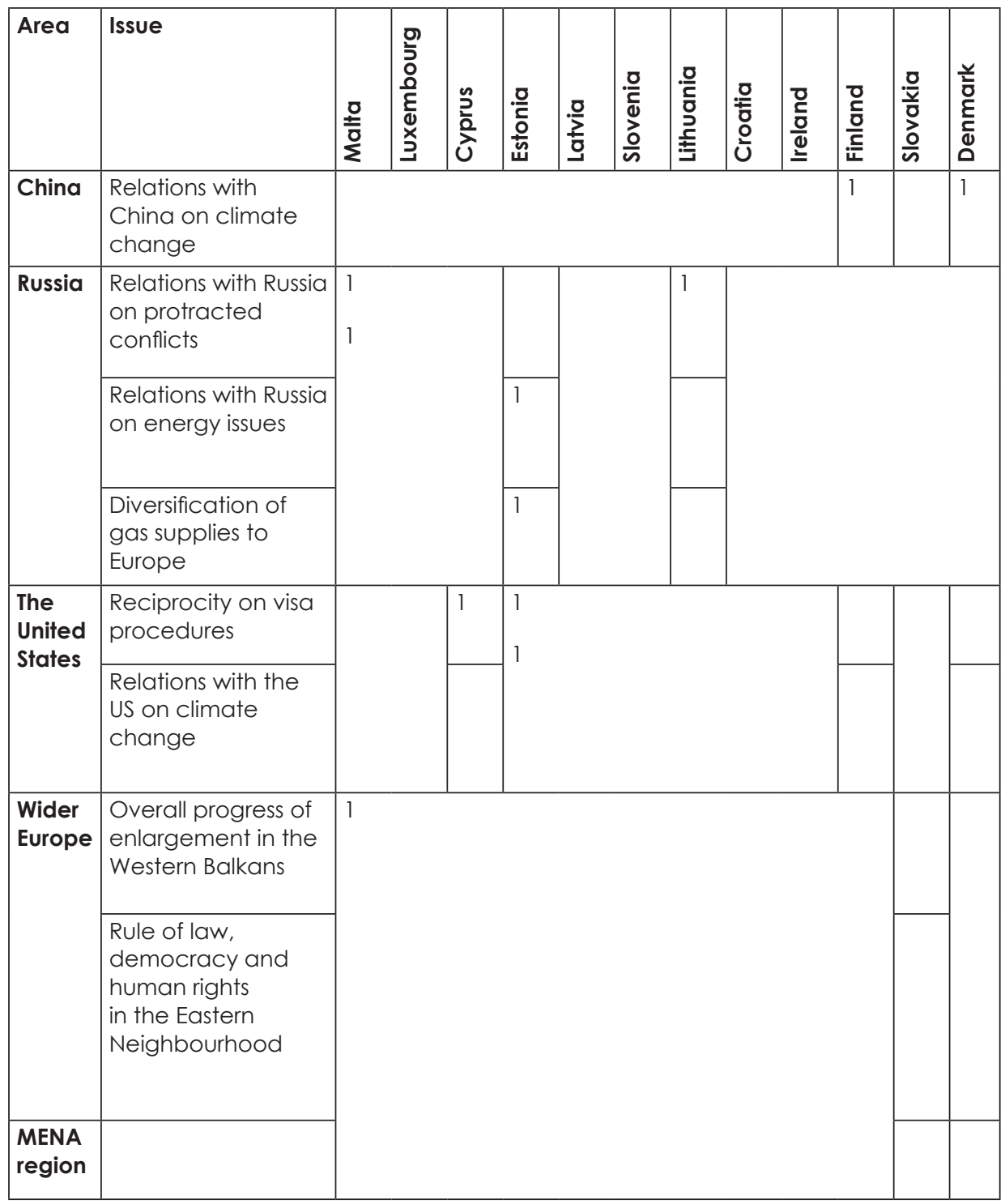

13 The ECFR Scorecard graded foreign policy activities of the EU member states in which these states were recognized as leaders in six areas: China, Russia, the United States, Wider Europe, the Middle East and North Africa (MENA) region, and Multilateral Issues and Crisis Management. Each area had a various number of issues graded. In 2011, China, Russia and the United States had four, Wider Europe and MENA region had five, and Multilateral Issues and Crisis Management seven. In 2012, relations with China and the United States had four grades, while relations with Russia and those with Wider Europe had five. Relations with the MENA region and Multilateral Issues and Crisis Management had six grades. In 2013, all of the areas had five issues that could have been graded. Therefore, the maximum number for each area in the three year period was the following: China 13, Russia 14, the United States 13, Wider Europe 15, MENA region 16, and Multilateral Issues and Crisis Management 18. 


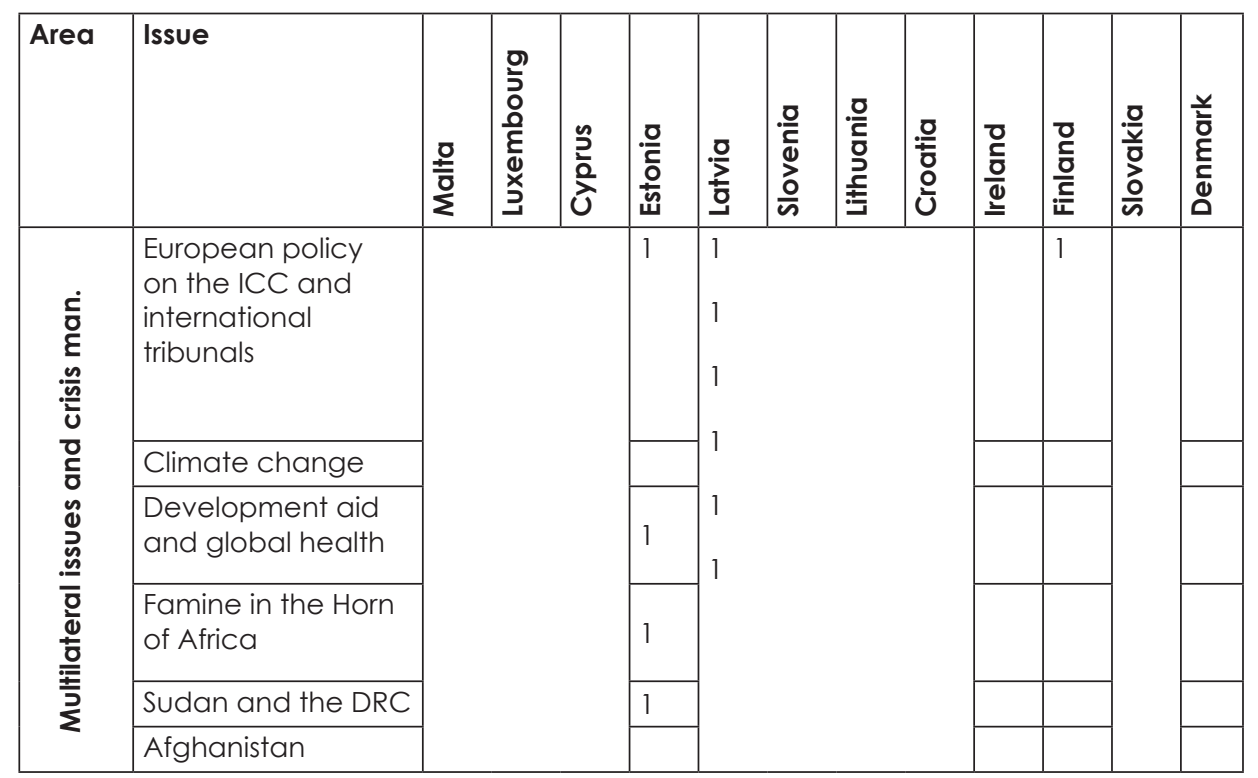

2012

\begin{tabular}{|c|c|c|c|c|c|c|c|c|c|c|c|c|c|}
\hline Area & Issue & $\frac{\text { o }}{\frac{7}{2}}$ & 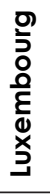 & $\stackrel{n}{\grave{c}}$ & $\begin{array}{l}\frac{0}{c} \\
\frac{0}{4} \\
\text { ய }\end{array}$ & $\frac{0}{\frac{0}{2}}$ & $\begin{array}{l}\frac{0}{\bar{c}} \\
\frac{0}{0} \\
\frac{0}{\omega}\end{array}$ & 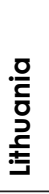 & $\begin{array}{l}\frac{0}{t ⿱ 亠 ⿻} \\
\frac{0}{u}\end{array}$ & $\begin{array}{l}\text { 을 } \\
\stackrel{0}{\underline{0}}\end{array}$ & 음 & $\frac{0}{\frac{0}{8}}$ & 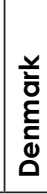 \\
\hline \multicolumn{14}{|l|}{ China } \\
\hline \multicolumn{14}{|l|}{ Russia } \\
\hline $\begin{array}{l}\text { The United } \\
\text { States }\end{array}$ & $\begin{array}{l}\text { Joint defence } \\
\text { projects within NATO } \\
\text { or CSDP to limit the } \\
\text { effects of budget } \\
\text { cuts }\end{array}$ & & & & 1 & & & & & & & & \\
\hline \multirow[t]{3}{*}{$\begin{array}{l}\text { Wider } \\
\text { Europe }\end{array}$} & $\begin{array}{l}\text { Encouraging Serbia } \\
\text { to normalise relations } \\
\text { with Kosovo }\end{array}$ & & & & & & & & & & 1 & & \\
\hline & $\begin{array}{l}\text { Putting pressure on } \\
\text { Belarus for political } \\
\text { liberalisation }\end{array}$ & & & & & & & & & & & & \\
\hline & $\begin{array}{l}\text { Pushing visa } \\
\text { liberalisation for } \\
\text { Russia, Ukraine and } \\
\text { Moldova }\end{array}$ & & & & 1 & 1 & & 1 & & & & 1 & \\
\hline
\end{tabular}




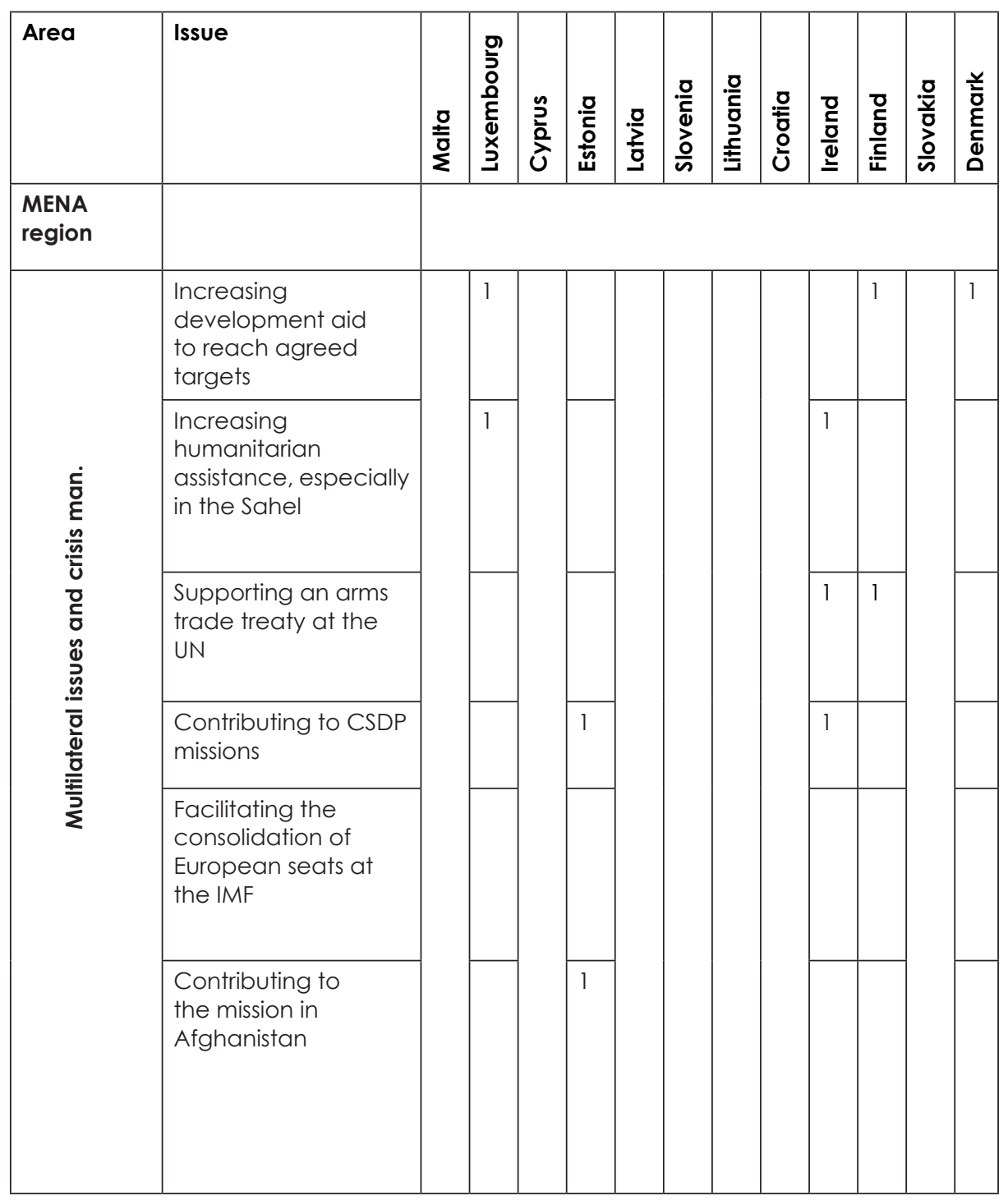




\begin{tabular}{|c|c|c|c|c|c|c|c|c|c|c|c|c|c|}
\hline Area & Issue & $\frac{\text { 온 }}{\text { 을 }}$ & 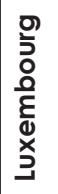 & $\sum_{0}^{2}$ & $\begin{array}{l}\frac{0}{c} \\
\frac{0}{4} \\
\text { 岀 }\end{array}$ & $\frac{0}{\frac{0}{3}}$ & $\begin{array}{l}\frac{0}{c} \\
\frac{1}{0} \\
\frac{0}{n}\end{array}$ & 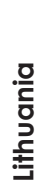 & $\begin{array}{l}\frac{0}{\frac{0}{t}} \\
\frac{0}{u} \\
\text { U. }\end{array}$ & 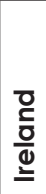 & $\frac{\text { 믈 }}{\text { 음 }}$ & $\begin{array}{l}\frac{0}{\frac{0}{y}} \\
\frac{0}{0}\end{array}$ & 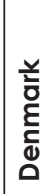 \\
\hline \multicolumn{14}{|l|}{ China } \\
\hline \multirow[t]{2}{*}{ Russia } & $\begin{array}{l}\text { Support } \\
\text { European } \\
\text { Commission } \\
\text { in resisting } \\
\text { Russian pressure } \\
\text { on Eastern } \\
\text { Partnership } \\
\text { countries }\end{array}$ & & & & & & & 1 & & & & & \\
\hline & $\begin{array}{l}\text { Action to } \\
\text { pressure Russia } \\
\text { to use its } \\
\text { leverage to stop } \\
\text { conflict in Syria }\end{array}$ & & & & & & & & & & & & \\
\hline \multicolumn{14}{|l|}{$\begin{array}{l}\text { The } \\
\text { United } \\
\text { States }\end{array}$} \\
\hline \multirow[t]{3}{*}{$\begin{array}{l}\text { Wider } \\
\text { Europe }\end{array}$} & $\begin{array}{l}\text { Support strong } \\
\text { line on the } \\
\text { release of } \\
\text { Tymoshenko }\end{array}$ & & & & & & & 1 & & & & & \\
\hline & $\begin{array}{l}\text { Support efforts } \\
\text { to achieve a } \\
\text { visa-free regime } \\
\text { with Georgia, } \\
\text { Ukraine and } \\
\text { Moldova }\end{array}$ & & & & 1 & 1 & & 1 & & & & 1 & \\
\hline & $\begin{array}{l}\text { Efforts to } \\
\text { diversify energy } \\
\text { supply in Europe } \\
\text { to reduce } \\
\text { dependency } \\
\text { from Russia }\end{array}$ & & & & 1 & & & & & & & 1 & \\
\hline
\end{tabular}




\begin{tabular}{|c|c|c|c|c|c|c|c|c|c|c|c|c|c|}
\hline Area & Issue & $\frac{0}{\frac{0}{0}}$ & 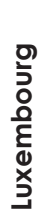 & 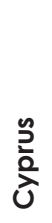 & 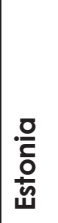 & $\frac{0}{2}$ & $\begin{array}{l}\frac{0}{2} \\
\frac{0}{0} \\
\frac{0}{\omega}\end{array}$ & 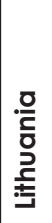 & $\begin{array}{l}\frac{0}{7} \\
\frac{0}{0} \\
\text { U }\end{array}$ & 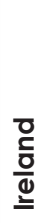 & $\frac{\text { Do }}{\frac{0}{0}}$ & $\frac{\frac{0}{y}}{\frac{i}{0}}$ & 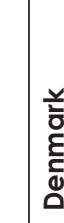 \\
\hline \multirow[t]{2}{*}{$\begin{array}{l}\text { MENA } \\
\text { region }\end{array}$} & $\begin{array}{l}\text { Pushing through } \\
\text { agreement } \\
\text { on eligibility } \\
\text { occupied } \\
\text { territories grants, } \\
\text { prices etc. }\end{array}$ & & & & & & & & & 1 & & & \\
\hline & $\begin{array}{l}\text { Support } \\
\text { closer security } \\
\text { cooperation in } \\
\text { the North Africa } \\
\text { region in } 2013\end{array}$ & 1 & & & & & & & & & & & \\
\hline \multirow{3}{*}{ 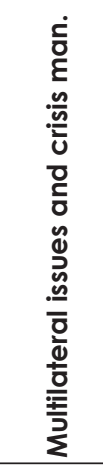 } & $\begin{array}{l}\text { Increase in } \\
\text { development } \\
\text { aid }\end{array}$ & & 1 & & 1 & 1 & & & & & 1 & 1 & 1 \\
\hline & $\begin{array}{l}\text { Increase in } \\
\text { humanitarian } \\
\text { aid }\end{array}$ & & 1 & & 1 & 1 & & & & 1 & 1 & 1 & \\
\hline & $\begin{array}{l}\text { Steps taken } \\
\text { to assist Syrian } \\
\text { refugees/IDPs }\end{array}$ & & 1 & 1 & & & & & & 1 & 1 & & 1 \\
\hline Total & & 1 & 5 & 2 & 11 & 4 & 0 & 7 & 0 & 9 & 11 & 6 & 9 \\
\hline
\end{tabular}


Table3. Eight EU member states with population between six and twelve million: "leaders" from the ECFR Scorecard, 2011-2013, by areas and issues:

\section{1}

\begin{tabular}{|c|c|c|c|c|c|c|c|c|c|}
\hline Area & Issue & $\frac{\text { 음 }}{\frac{0}{2}}$ & $\stackrel{\frac{0}{5}}{\frac{5}{2}}$ & 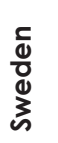 & 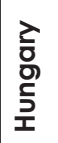 & $\frac{\frac{.0}{\overline{0}}}{\underline{\underline{d}}}$ & $\begin{array}{l}\bar{\delta} \\
\text { ơ } \\
\text { ț } \\
\text { o }\end{array}$ & $\frac{5}{\frac{5}{0}}$ & 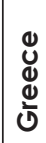 \\
\hline \multirow[t]{2}{*}{ China } & $\begin{array}{l}\text { Relations with China on } \\
\text { climate change }\end{array}$ & & & 1 & \multirow{2}{*}{\multicolumn{2}{|c|}{1}} & & & \\
\hline & $\begin{array}{l}\text { Relations with China on the } \\
\text { Arab Awakening }\end{array}$ & & & & & & & & \\
\hline \multirow[t]{4}{*}{ Russia } & $\begin{array}{l}\text { Rule of law and human } \\
\text { rights in Russia }\end{array}$ & \multirow{4}{*}{\multicolumn{2}{|c|}{1}} & 1 & & & & & \\
\hline & $\begin{array}{l}\text { Relations with Russia on } \\
\text { protracted conflicts }\end{array}$ & & & & 1 & & \multicolumn{2}{|l|}{1} & \\
\hline & $\begin{array}{l}\text { Relations with Russia on } \\
\text { energy issues }\end{array}$ & & & & 1 & & & & \\
\hline & $\begin{array}{l}\text { Diversification of gas } \\
\text { supplies to Europe }\end{array}$ & & & 1 & 1 & & & & \\
\hline \multirow[t]{2}{*}{$\begin{array}{l}\text { The United } \\
\text { States }\end{array}$} & $\begin{array}{l}\text { Reciprocity on visa } \\
\text { procedures }\end{array}$ & 1 & \multirow{2}{*}{\multicolumn{3}{|c|}{1}} & 1 & & & \\
\hline & $\begin{array}{l}\text { Relations with the US on } \\
\text { climate change }\end{array}$ & & & & & & & & \\
\hline \multirow[t]{4}{*}{ Wider Europe } & $\begin{array}{l}\text { Overall progress of } \\
\text { enlargement in the } \\
\text { Western Balkans }\end{array}$ & & & 1 & 1 & & & & \\
\hline & Kosovo & & 1 & & & & & & \\
\hline & $\begin{array}{l}\text { Relations with Turkey on } \\
\text { regional issues }\end{array}$ & & & 1 & & & & & \\
\hline & $\begin{array}{l}\text { Rule of law, democracy } \\
\text { and human rights in the } \\
\text { Eastern Neighbourhood }\end{array}$ & & & 1 & & 1 & & & \\
\hline MENA region & & & & & & & & & \\
\hline
\end{tabular}




\begin{tabular}{|c|c|c|c|c|c|c|c|c|c|}
\hline Area & Issue & $\frac{\text { 음 }}{\frac{5}{2}}$ & $\frac{0}{\frac{0}{n}}$ & 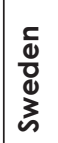 & $\begin{array}{l}\text { 흠 } \\
\text { 은 } \\
\text { 꼬 }\end{array}$ & 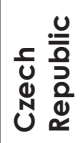 & 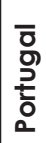 & $\frac{\frac{5}{2}}{\frac{0}{0}}$ & 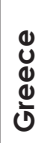 \\
\hline \multirow{6}{*}{$\begin{array}{l}\text { Multilateral } \\
\text { issues and } \\
\text { crisis man. }\end{array}$} & $\begin{array}{l}\text { European policy on UN } \\
\text { reform }\end{array}$ & & & & & & 1 & & \\
\hline & $\begin{array}{l}\text { European policy on the } \\
\text { ICC and international } \\
\text { tribunals }\end{array}$ & & & 1 & & 1 & & & \\
\hline & Climate change & & & 1 & & & & & \\
\hline & $\begin{array}{l}\text { Development aid and } \\
\text { global health }\end{array}$ & \multirow[t]{3}{*}{1} & & 1 & & & & & \\
\hline & $\begin{array}{l}\text { Famine in the Horn of } \\
\text { Africa }\end{array}$ & & & 1 & & & & & \\
\hline & Sudan and the DRC & & & 1 & & & & & \\
\hline
\end{tabular}

2012

\begin{tabular}{|c|c|c|c|c|c|c|c|c|c|}
\hline Area & Issue & $\begin{array}{l}\text { 음 } \\
\frac{0}{2} \\
\frac{0}{2}\end{array}$ & $\frac{0}{\frac{0}{n}}$ & $\begin{array}{l}\frac{c}{0} \\
\frac{1}{d} \\
\sum_{n}^{2}\end{array}$ & 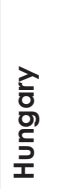 & $\frac{\frac{.0}{0}}{\underline{0}}$ & $\begin{array}{l}\bar{g} \\
\text { D̆ } \\
\text { 는 }\end{array}$ & $\frac{\varepsilon}{\frac{5}{0}}$ & 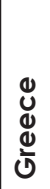 \\
\hline China & $\begin{array}{l}\text { Promoting human rights } \\
\text { in China }\end{array}$ & & & 1 & & 1 & & & \\
\hline Russia & $\begin{array}{l}\text { Promoting human rights } \\
\text { in Russia }\end{array}$ & & & 1 & & & & & \\
\hline $\begin{array}{l}\text { The United } \\
\text { States }\end{array}$ & $\begin{array}{l}\text { Joint defence projects } \\
\text { within NATO or CSDP } \\
\text { to limit the effects of } \\
\text { budget cuts }\end{array}$ & & & 1 & & 1 & & & \\
\hline \multirow[t]{4}{*}{$\begin{array}{l}\text { Wider } \\
\text { Europe }\end{array}$} & $\begin{array}{l}\text { Encouraging Serbia to } \\
\text { normalise relations with } \\
\text { Kosovo }\end{array}$ & & 1 & & & & & & \\
\hline & $\begin{array}{l}\text { Pushing visa } \\
\text { liberalisation for Turkey }\end{array}$ & & & 1 & & & & & \\
\hline & $\begin{array}{l}\text { Putting pressure on } \\
\text { Belarus for political } \\
\text { liberalisation }\end{array}$ & & & 1 & & & & & \\
\hline & $\begin{array}{l}\text { Pushing visa } \\
\text { liberalisation for Russia, } \\
\text { Ukraine and Moldova }\end{array}$ & & & & 1 & 1 & & & \\
\hline
\end{tabular}




\begin{tabular}{|c|c|c|c|c|c|c|c|c|c|}
\hline Area & Issue & 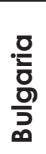 & $\frac{\text { on }}{\frac{1}{2}}$ & 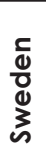 & 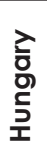 & 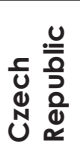 & $\begin{array}{l}\overline{0} \\
\text { ơ } \\
\text { t⿱亠𧘇口․ }\end{array}$ & $\frac{\varepsilon}{\frac{5}{5}}$ & 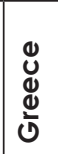 \\
\hline MENA region & $\begin{array}{l}\text { Improving financial } \\
\text { support for MENA }\end{array}$ & & & 1 & & & & & \\
\hline \multirow[t]{6}{*}{$\begin{array}{l}\text { Multilateral } \\
\text { issues and } \\
\text { crisis man. }\end{array}$} & $\begin{array}{l}\text { Increasing development } \\
\text { aid to reach agreed } \\
\text { targets }\end{array}$ & & & 1 & & & & & \\
\hline & $\begin{array}{l}\text { Increasing } \\
\text { humanitarian } \\
\text { assistance, especially in } \\
\text { the Sahel }\end{array}$ & & & 1 & & & & & \\
\hline & $\begin{array}{l}\text { Supporting an arms } \\
\text { trade treaty at the UN }\end{array}$ & 1 & & 1 & & & & 1 & \\
\hline & $\begin{array}{l}\text { Contributing to CSDP } \\
\text { missions }\end{array}$ & & 1 & & & & & 1 & \\
\hline & $\begin{array}{l}\text { Facilitating the } \\
\text { consolidation of } \\
\text { European seats at the } \\
\text { IMF }\end{array}$ & & 1 & & & 1 & & 1 & \\
\hline & $\begin{array}{l}\text { Contributing to the } \\
\text { mission in Afghanistan }\end{array}$ & 1 & & 1 & 1 & & & & \\
\hline
\end{tabular}

2013

\begin{tabular}{|c|c|c|c|c|c|c|c|c|c|}
\hline Area & Issue & $\begin{array}{l}\text { 음 } \\
\frac{\mathrm{o}}{2}\end{array}$ & $\stackrel{\frac{0}{2}}{\frac{\hbar}{2}}$ & $\frac{c}{d}$ & 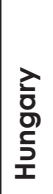 & 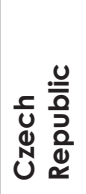 & $\begin{array}{l}\overline{\mathrm{g}} \\
\text { ơ } \\
\text { ț } \\
\text { 은 }\end{array}$ & $\frac{\frac{\varepsilon}{5}}{\frac{7}{0}}$ & 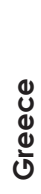 \\
\hline \multicolumn{10}{|l|}{ China } \\
\hline \multirow[t]{3}{*}{ Russia } & $\begin{array}{l}\text { Support European } \\
\text { Commission in resisting } \\
\text { Russian pressure on Eastern } \\
\text { Partnership countries }\end{array}$ & \multirow{3}{*}{\multicolumn{2}{|c|}{$\begin{array}{l}1 \\
1\end{array}$}} & 1 & 1 & & & & \\
\hline & $\begin{array}{l}\text { Support strong European } \\
\text { position on rule of law and } \\
\text { human rights and press } \\
\text { freedom }\end{array}$ & & & & & & & & \\
\hline & $\begin{array}{l}\text { Action to pressure Russia } \\
\text { to use its leverage to stop } \\
\text { conflict in Syria }\end{array}$ & & & & & & & & \\
\hline $\begin{array}{l}\text { The United } \\
\text { States }\end{array}$ & Pushing for TTIP & & & 1 & & & & & \\
\hline
\end{tabular}




\begin{tabular}{|c|c|c|c|c|c|c|c|c|c|}
\hline Area & Issue & $\begin{array}{l}\frac{0}{0} \\
\frac{0}{2} \\
\frac{0}{2}\end{array}$ & 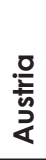 & 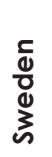 & 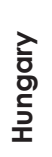 & 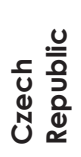 & 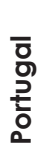 & $\frac{\varepsilon}{\frac{5}{0}}$ & 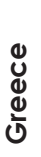 \\
\hline \multirow[t]{5}{*}{$\begin{array}{l}\text { Wider } \\
\text { Europe }\end{array}$} & $\begin{array}{l}\text { Support strong line on the } \\
\text { release of Tymoshenko }\end{array}$ & & & 1 & & \multirow{5}{*}{\multicolumn{2}{|c|}{1}} & & \\
\hline & $\begin{array}{l}\text { Support efforts to achieve } \\
\text { a visa-free regime with } \\
\text { Georgia, Ukraine and } \\
\text { Moldova }\end{array}$ & & & & \multirow[t]{2}{*}{1} & & & & \\
\hline & $\begin{array}{l}\text { Efforts to diversify energy } \\
\text { supply in Europe to reduce } \\
\text { dependency from Russia }\end{array}$ & & & & & & & & \\
\hline & $\begin{array}{l}\text { Steps to support opening } \\
\text { Chapter } 23 \text { and } 24 \text { in } \\
\text { accession negotiations } \\
\text { with Turkey }\end{array}$ & & & 1 & & & & & \\
\hline & $\begin{array}{l}\text { Support for a strong } \\
\text { European position Serbia } \\
\text { and Kosovo negotiations }\end{array}$ & & 1 & & & & & & \\
\hline \multicolumn{10}{|l|}{$\begin{array}{l}\text { MENA } \\
\text { region }\end{array}$} \\
\hline \multirow{4}{*}{ 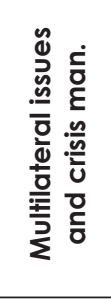 } & $\begin{array}{l}\text { Increase in development } \\
\text { aid }\end{array}$ & & 1 & 1 & \multirow{4}{*}{\multicolumn{3}{|c|}{1}} & & \\
\hline & $\begin{array}{l}\text { Increase in humanitarian } \\
\text { aid }\end{array}$ & & 1 & 1 & & & & & \\
\hline & $\begin{array}{l}\text { Steps taken to assist Syrian } \\
\text { refugees/IDPs }\end{array}$ & & 1 & 1 & & & & & \\
\hline & Support for Somalia & & & 1 & & & & & \\
\hline Total & & 4 & 8 & 31 & 6 & 10 & 3 & 6 & 0 \\
\hline
\end{tabular}


Table 4. States and areas of foreign policy activity according to the ECFR Scorecard, 2011 -2013:

\begin{tabular}{|c|c|c|c|c|c|c|c|}
\hline State & China & Russia & $\begin{array}{l}\text { The } \\
\text { United } \\
\text { States }\end{array}$ & $\begin{array}{c}\text { The } \\
\text { Wider } \\
\text { Europe }\end{array}$ & $\begin{array}{l}\text { MENA } \\
\text { region }\end{array}$ & $\begin{array}{l}\text { Multilateral } \\
\text { issues and } \\
\text { crisis man. }\end{array}$ & Total \\
\hline Malta & & & & & 1 & & 1 \\
\hline Luxembourg & & & 1 & 5 & 5 & & \\
\hline Cyprus & & & 1 & & & 1 & 2 \\
\hline Estonia & & 2 & & 3 & & 5 & 11 \\
\hline Latvia & & & & 2 & & 2 & 4 \\
\hline Slovenia & & & & & & & 0 \\
\hline Lithuania & & 4 & & 3 & & & 7 \\
\hline Croatia* & & & & & & & 0 \\
\hline Ireland & & & & & 1 & 8 & 9 \\
\hline Finland & 1 & & 1 & 1 & & 8 & 11 \\
\hline Slovakia & & & & 4 & & 2 & 6 \\
\hline Denmark & 1 & & 1 & & & 7 & 9 \\
\hline
\end{tabular}

*Data available only from July 2013.

\begin{tabular}{|c|c|c|c|c|c|c|c|}
\hline Bulgaria & & & 1 & & & 3 & 4 \\
\hline Austria & & & & 3 & & 5 & 8 \\
\hline Sweden & 2 & 6 & 2 & 7 & 1 & 13 & 31 \\
\hline Hungary & & 2 & & 3 & & 1 & 6 \\
\hline Czech Republic & 1 & 3 & 2 & 2 & & 2 & 10 \\
\hline Portugal & 1 & & 1 & & & 1 & 3 \\
\hline Belgium & & & 1 & 1 & & 4 & 6 \\
\hline Greece & & & & & & & 0 \\
\hline
\end{tabular}

The analysis of the leadership initiatives (from the ECFR Scorecard, 20112013) of the twelve smallest EU members states by population shows that "smallness", measured by population, need not be the limiting factor in their foreign policy activism. However, the results from the Scorecard have to be interpreted with considerable caution, and be related to specific knowledge about each of the studied states, especially regarding their geopolitical position, capacities of their economy, their institutions, traditional goals and features of their foreign policy. The foreign policy of states classified as "small" cannot be explained only by quantitative data and factors such as their population, total GDP and GDP per capita, 
as it was elaborated in the previous sections. However, these factors, according to the results presented in this article, have an impact on the foreign policy activism of small states, judging by the number and scope of the analyzed activities.

Among the twelve smallest EU member states by population (Malta, Luxembourg, Cyprus, Estonia, Slovenia, Latvia, Lithuania, Croatia, Ireland, Finland, Slovakia, Denmark), there are three (Ireland, Finland and Denmark) which are not amongthe twelve smallest economies of the EU, given the fact that they have a very high GDP per capita. At the same time, three states that are not among the twelve least populated states of the EU belong to the group of the EU's twelve smallest economies (Bulgaria, Hungary, and the Czech Republic), with their GDP per capita being well below the EU28 average (Bulgaria has the lowest GDP per capita of all the EU members). ${ }^{14}$

The twelve least populated EU member states (if we take population as a factor that determines "smallness") referred to as the "smallest" member states 15 (that are shown in Table 2) demonstrate a very different numbers of foreign policy activities in which they were recognized as "leaders". Those with most activities were Finland and Estonia (11 activities each), followed by Ireland and Denmark ( 9 activities each). Estonia, with a population of only 1.3 million presented a high level of foreign policy activism. Nevertheless, most of these activities were oriented towards the neighboring countries (Russia) and the Wider Europe region (The Eastern Partnership countries in particular: Georgia, Ukraine, and Moldova). The case of Estonia shows that population size need not be a decisive factor influencing foreign policy activism, although the mentioned activities are mainly focused towards neighboring states and regions.

Finland, a neutral and economically highly developed state, showed a respectful level of leadership initiatives in the analyzed period. However, Finland's foreign policy activities were mostly oriented towards multilateral issues, crisis management, and less towards the Wider Europe region.

14 Romania is the 17th economy of the EU, although it is the EU's seventh most populated state. It was not particularly analyzed in this paper, since in 2013 it had 20.1 million inhabitants. However, its foreign policy activism according to ECFR Scorecard showed a disproportionately low level of activities in comparison to its population.

15 There is also a noticeable difference in the size of the population of the 12 smallest EU members. The population of Denmark (5.6 million) is 14 times bigger than the population of Malta (0.4 million). 
Issues related to climate change were Finland's priority within the EU, particularly relations with two of the World's biggest polluters - China and the U.S., which could also be perceived as an indicator of Finland's global priorities (global warming). Ireland, an economically highly developed state, presented nine leadership activities, which were all but one devoted to multilateral issues and crisis management, with a recognizable humanitarian character. Denmark, a small state by population, but a developed economy and a NATO member since its founding, focused its activities on multilateral issues and crisis management. In addition, as well as Finland, it showed leadership in climate change issues in relation with China and the U.S. Luxembourg, the most developed EU member state, focused all of its foreign policy leadership initiatives towards multilateral issues and crisis management, increasing its humanitarian and development aid, and helping Syrian refugees.

According to the Scorecard, Lithuania devoted all of its leadership activities (7) to one neighboring state (Russia) and its neighboring region, the Wider Europe. Lithuania is a good example of a small state that focused its foreign policy initiatives primarily towards its neighborhood (especially towards Russia). Latvia had four activities, two of which were aimed at the visa regime liberalization with Eastern Partnership countries and the other two at multilateral issues and crisis management. The issue of the visa liberalization regime is an issue in which most of the small EU members from Central and Eastern Europe showed leadership initiatives, since they are geographically and historically mostly connected with the states of the Eastern Partnership. The other important interest for the countries focused on the Wider Europe region was the effort to diversify energy supply in Europe in order to reduce dependency on Russia.

Geographical proximity to Russia is closely linked with the Baltic States' preferences in their shared eastern neighborhood region. Thus, the European neighborhood policy helped them to redefine relations with Russia, as well as to find their own place within the EU. Therefore, immediately after joining the EU, all three countries announced the Eastern partnership as one of their top priorities (see Pastore 2013: 69-70). In most cases, small new memberstates have learned the importance of a constructive interestmediation style. One such example is Lithuania which has learned a lesson on the need for compromise. After the 2008 elections, Lithuanian foreign 
policy changed its rhetoric from troublemaker to a more pragmatic and cooperative approach, while the policy priorities remained the same. This pragmatic approach was maintained during Lithuania's EU Presidency in 2013, e.g., with the government strictly following the Brussels official line. Another example is Estonia. Despite bilateral problems with Russia, it sought to escape the image of a "one-issue" state by purposefully taking a restrained approach and downplaying them as "technical" problems (see Vilpišauskas 2011).

Cyprus $^{16}$ presented two leadership activities (assisting Syrian refugees and reciprocity on visa procedures with the U.S.) ${ }^{17}$, while Malta had one, related to its southern neighborhood (North Africa region), where it supported closer security cooperation in 2013. Namely, Malta's foreign policy seeks to use its geopolitical relevance to maximize its influence. Therefore, it is focused foremost on stability in the Mediterranean region, from which non-military threats, such as irregular migration, emerge. Given its relevance for national security, migration has become Malta's highly salient issue in the EU (Pastore 2013: 71-72).

Two of the twelve analyzed states were not recognized as "leaders" in foreign policy activities according to the Scorecard. The first is Croatia (which joined the EU only in July 2013) and the second one is Slovenia, which did not manage to achieve a single leadership initiative in three years. However, one has to bear in mind that the period being analyzed is one in which Slovenia and Croatia were faced with large economic difficulties. Slovenia's key foreign policy interests were focused on its geographical vicinity, i.e. the Western Balkans (Pastore 2013: 71).

Of the states from the second group defined in our research (with a population between six and twelve million), the differences in the scope of foreign policy activities and especially the number were also visible. Greece, the most populous among the twenty states, did not manage to achieve a single leadership initiative in the 2011-2013 period, according to the Scorecard. The immense socio-economic difficulties that Greece has been facing represent the most probable explanation of this condition. Portugal had three initiatives and Bulgaria four. Both

16 One needs to take into account that some states were more affected by the economic crisis in the analyzed period, which influenced their foreign policy activism.

17 Generally, theforeign policy preferences of Cyprus in the EU are explicitly linked to its geographic proximity to Turkey. 
states belong to the so-called "European periphery" and have been faced with serious socio-economic difficulties, as well as Hungary, whose leadership roles were primarily oriented towards its eastern neighborhood (Wider Europe). Belgium devoted most of its initiatives to multilateral issues and crisis management. As a state with a very "sensitive" political situation, and a high level of socio-economic development, it focused its activism on multilateral initiatives and crisis management. Austria, traditionally a neutral state, devoted its foreign policy activities to similar issues, but it also showed leadership related to the Western Balkans (especially to Kosovo), since it is mostly economically involved in the region. The Czech Republic showed 10 leadership roles during the analyzed period, which were almost evenly distributed within all areas of interest, except for the MENA region. Finally, Sweden showed a disproportionately (considering its population of 9.6 million) high level of leadership activism. Sweden was recognized as a leader in 31 activities, being the only state that showed leadership in all studied areas. As a traditionally neutral state, it demonstrated a high level of foreign policy activism that is common for much bigger states, such as Italy, France, Germany and the United Kingdom. Namely, it was recognized as a leader in 13 issues related to multilateralism and crisis management, but was also very active in relations with Russia and Wider Europe.

\section{Conclusion}

In order to verify our second hypothesis, we compared the results from the ECFR Scorecard (Tables 2, 3 and 4) with the numbers in Table 1 and Figure 1. Among other data, the level of total GDP and GDP per capita for each state is presented. We also recognized the annual growth rate in the years 20092013 as a probable indicator of foreign policy activism (see Figure 2).

Finally, in order to verify our third hypothesis, the results from the ECFR Scorecard (Tables 1, 2 and 3) were studied in detail.

Consequently, Table 5 presents the results of attempting to verify our hypotheses. We have compared the results from the ECFR Scorecard (Tables 1, 2 and 3) to Figure 1, which presents the population of the analyzed states. 
Table 5. Verification of hypotheses for the studied states:

\begin{tabular}{|l|c|l|l|l|}
\hline State & $\begin{array}{l}\text { No. of } \\
\text { initiatives }\end{array}$ & $\begin{array}{l}\text { Main hypothesis } \\
(\mathbf{1})\end{array}$ & Hypothesis 2 & Hypothesis 3 \\
\hline Malta & $\mathbf{1}$ & Verified & Partially verified & Verified \\
\hline Luxembourg & $\mathbf{5}$ & Not verified $(+)$ & Verified & Not verified \\
\hline Cyprus & $\mathbf{2}$ & Verified & Verified & Verified \\
\hline Estonia & $\mathbf{1 1}$ & Not verified $(+)$ & Verified & Partially verified \\
\hline Latvia & $\mathbf{4}$ & Partially verified & Partially verified & Partially verified \\
\hline Slovenia & $\mathbf{0}$ & Not verified $(--)$ & Verified & No data to conclude \\
\hline Lithuania & $\mathbf{7}$ & Not verified $(+)$ & Not verified $(+)$ & Verified \\
\hline Croatia & $\mathbf{0}$ & Not verified $(--)$ & Verified & No data to conclude \\
\hline Ireland & $\mathbf{9}$ & Not verified $(+)$ & Verified & Not verified \\
\hline Finland & $\mathbf{1 1}$ & Not verified $(+)$ & Verified & Partially verified \\
\hline Slovakia & $\mathbf{6}$ & Partially verified & Partially verified & Verified \\
\hline Denmark & $\mathbf{9}$ & Not verified $(+)$ & Verified & Not verified \\
\hline
\end{tabular}

\begin{tabular}{|l|c|l|l|l|}
\hline Bulgaria & $\mathbf{4}$ & Not verified (-) & Verified & Partially verified \\
\hline Austria & $\mathbf{8}$ & Partially verified & Partially verified & Partially verified \\
\hline Sweden & $\mathbf{3 1}$ & Not verified (++) & Verified & Not verified \\
\hline Hungary & $\mathbf{6}$ & Not verified (-) & Verified & Verified \\
\hline $\begin{array}{l}\text { Czech } \\
\text { Republic }\end{array}$ & $\mathbf{1 0}$ & Partially verified & Partially verified & Partially verified \\
\hline Portugal & $\mathbf{3}$ & Not verified (--) & Verified & Not verified \\
\hline Belgium & $\mathbf{6}$ & Not verified (-) & Not verified (-) & Not verified data to \\
\hline Greece & $\mathbf{0}$ & Not verified (--) & Verified & $\begin{array}{l}\text { No conclude } \\
\text { cond }\end{array}$ \\
\hline
\end{tabular}

It can be concluded that the first hypothesis was completely verified in just two cases (Malta, Cyprus). All other states showed some level of discrepancy between their population and the number of recognized leading EU foreign policy roles, whether they had a high number of recognized leading activities and relatively small population compared to other analyzed states, or vice versa. The hypothesis was partially verified for states that did not show a significant level of divergence between the population and the number of initiatives. The verification of the first hypothesisis closely related with the verification of the second one, 18 recognized as crucial within the analyzed period (2011-2013). To verify the second hypothesis the annual GDP growth

18 The level of economic development (measured by total GDP and GDP per capita) as well as the current economic difficulties (recession, high unemployment etc.) affect the intensity of foreign policy activism of "small" EU member states. A higher level of GDP per capita and a better economic performance in the analyzed period mean a higher level of foreign policy activism (and vice versa). 
rate in the years 2009-201319(besides the total GDP and GDP per capita) was analyzed (Figure 2). This period presents the time of the worst economic crisis most of the analyzed states were faced with in decades. Since the ECFR Scorecard did not exist prior to 2011, one cannot claim with the utmost certainty that small states' foreign policy initiatives were more numerous prior to the economic crisis. However, since all the analyzed states are still recovering from the recession most of them were affected by in 2009, the number of their foreign policy activities appears to be closely linked to the economic difficulties that they have been coping with, and in some of the cases to the level of GDP per capita. A higher level of GDP per capita means more opportunities for multilateral actions, aid, assistance etc. Therefore, it could be suggested that there exists a correlation between the severity of the economic crisis, and the lack of foreign policy activism of the states analyzed during the five-year period (the longer the economic crisis, the less the state has foreign policy activities recognized by the ECFR Scorecard).

Figure 2. Total GDP of the analyzed states, annual growth rate in percentage, 2009-2013:

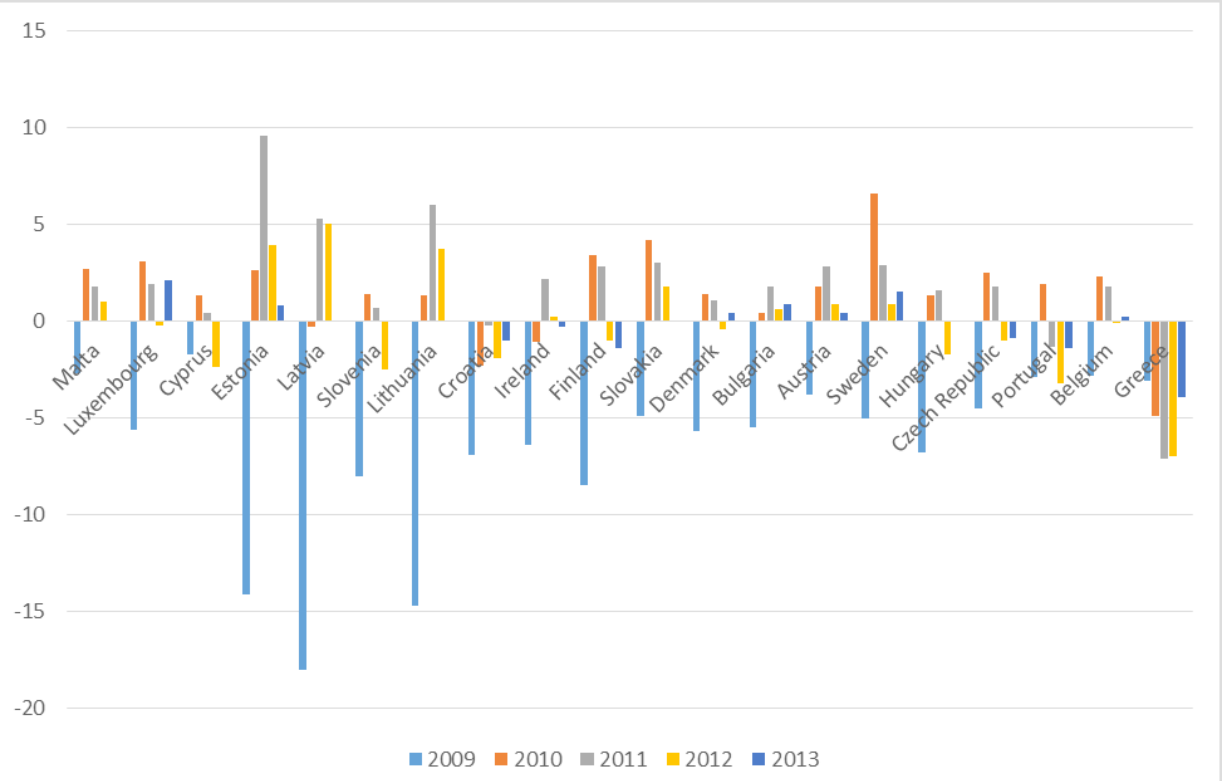

Hypothesis 3 was verified mainly for the new small EU member states,

19 The data for the year 2013 were not available for all studied states from the same source so they were not included in this Figure.

See: http://data.worldbank.org/indicator/NY.GDP.MKTP.KD.ZG. 
which were mainly focused on the political and economic situation in their eastern neighborhood and their energy security, since most of them are still heavily dependent on gas imports from Russia. Currently, they are either not interested or not capable (sometimes both) in becoming leaders or in resolving issues that do not affect them directly. Small EU member states with a higher level of GDP per capita and less economic difficulties (mostly from Western and Northern Europe) are more focused on multilateral issues and crisis management. They are able to deal with these issues, notwithstanding their own economic difficulties, as they do not face such immense political and economic problems (that pose internal security challenges to them) in their immediate surroundings (unlike the "small" new members from Central, Eastern and Southeastern Europe). The results show that geographical proximity influences the scope and intensity of EU foreign policy initiatives in the case of small states on the EU's Eastern and Southeastern "frontline"(more than other small EU member states).

Given the presented results, more of the hypotheses about the linkages between quantitative factors have been disapproved than proved (the findings especially undermine the first hypothesis). Therefore, there is a need for a more complex analysis taking different, more subjective perceptions that could cast a different light on the findings. The qualitative approach emphasizes the role a small state itself takes in relation to its wider environment. Namely, small states might adopt a low-profile approach, keep out of the limelight and avoid attracting attention (Baillie 1998: 203). Several of the small states discussed are the ones that regard NATO or the US as the most decisive forces in their national security and wellbeing, and may be taking significant initiatives in that area, while others would pursue more normatively-motivated initiatives. Therefore, there is a need for a more complex analysis, taking the aforementioned qualitative criteria into account, especially due to the fact that some small states intervene or act as "leaders" only in the issues of primary importance for them. 


\section{( Bibiography}

Baillie, S., 1998. The Position of Small States in the EU.In: Goetschel, L. ed. Small States inside and outside the European Union. Interests and Policies.Boston: Kluwer Academic Publishers.

Buchowski, C., Šabič, Z., eds.,2002. Small States in the Post -Cold World, Slovenia and NATO Enlargement. London: Praeger: 1-24.

Benko, V., 1992. O vprašanju prioritet v zunanji politiki Slovenije. Teorija in Praksa, 29 (1/2): 3-11.

Benko, V., 1997.Znanost o mednarodnih odnosih. Ljubljana: FDV.

Bojinovic, A., 2005. Geographical Proximity and Historical Experience as a Basis for Active Foreign Policy Strategy of Small European States - the Case of Austria and Slovenia regarding the Western Balkans. Politics in Central Europe, 1(1): 8-29. Available at: http:/ nbnresolving.de/urn:nbn:de:0168-ssoar-61231.

Braveboy-Wagner, J., 2010. Opportunities and Limitations of the Exercise of Foreign Policy Power by a Very Small State: The Case of Trinidad and Tobago. Cambridge Review of International Affairs, 23(3): 407-425.

Czina, V., 2014. Small Member States as policy actors in the EU: defining a new strategy through the case of Hungary, submitted to the UACES conference: New Horizons in European Studies, held in Auston University, Birmingham, UK, 24-25 April 2014, available at: http:// www.vaces.org

European Foreign Policy Scorecard 2012, European Council on Foreign Relations, http:// www.ecfr.eu

European Foreign Policy Scorecard 2013, European Council on Foreign Relations, http:// www.ecfr.eu

European Foreign Policy Scorecard 2014, European Council on Foreign Relations, http://www.ecfr.eu

Goetschel, L., 2000.Power and identity: Small states and the common foreign and security policy of the EU. Bern: Universität Bern, Institut 
für Politikwissenschaft, National Research Program Foundations and Possibilities of Swiss Foreign Policy, available at http://www.snf. ch/NFP/nfp42/synthese/33Goetschelsynthesis42.pdf laccessed 8 March 2014).

Hanggi, H., Regnier, P., 2000. The Small State and the Triad: the Case of Switzerland's Foreign Policy Towards East Asia, Study in NRF Policy. National Foreign Policy Program.

Hill, C., 2003. The Changing Politics of Foreign Policy. Houndmills: Palgrave. Holm, H -H., 2002. Danish Foreign Policy Activism: The Rise and Decline. In: Heurlin, B. and Mouritzen, H., eds. Danish Foreign Policy Yearbook 2002. Kbh:DUPI: 19-46.

Howard Grøn, C., Wivel, A., 2011. Maximizing Influence in the European Union after the Lisbon Treaty: From Small State Policy to Smart State Strategy. Journal of European Integration, 33(05): 523-39.

Keating, M., McEwen, N., Harvey, M., 2014. The Role of Small States in the European Union: lessons for Scotland, Evidence Presented to the Scottish Parliament Europe and External Affairs Committee, 16 January 2014, available at: http://www.futureukandscotland. ac.uk/papers/role-small-states-european-union-lessons-scotland.

Lehne, S., 2012. The Big Three in EU Foreign Policy, The Carnegie Papers, Carnegie Endowment for International Peace, available at: http:// www.CarnegieEndowment.org/pubs.

Lindell, U.,Persson, S., 1986. The Paradox of Weak State Power: A Research and Literature Overview. Conflict and Cooperation, 21 (2): 79-97.

Luša, Đ., Mijić, P., 2012. Vanjska politika malih država - normativna moć kao faktor utjecaja $\cup$ međunarodnim odnosima. Političke perspective, 3:39-67.

Luša, Đ., Kurečić, P., 2014. The Economic Growth of Small States and Small Economies in Regional Economic Integrations: Similarities and Differences. Journal of Education Culture and Society, 14(1):261-285.

Mix, Derek E., 2013. The European Union: Foreign and Security Policy, CRS Report for Congress, Congressional Research Service, 8 April 2013, available at http://www.crs.gov. 
Mouritzen, H., 1998.Theory and Reality of International Politics. Aldershot: Asgate.

Mouritzen, H., Wivel, A., 2005.The Geopolitics of Euro-Atlantic Integration. London: Routledge.

Nasra, S., 2010.Weak Power, Great Influence: Small States in EU Foreign Policy. The Case of Belgium and Greece. EUIA 2010 Conference. Brussels, 22-24 April 2010, available at: http://www.ies.be/files/ Nasra -El.pdf.

Panke, D., 2010. Small States in the European Union: Structural Disadvantages in EU Policy Making and Counter - Strategies. Journal of European Public Policy, 17(6): 799-817.

Pastore, G., 2013. Small New Member States in the EU Foreign Policy: Toward "Small State Smart Strategy"? Baltic Journal of Political Science, December (2): 67-84.

Rolenc, J.M., 2013. Means, Goals and Sources of Foreign Policy: The Case of Sweden, Paper draft for the ISA 2013 convention, 3-6 April, San Francisco, available at http:// iles.isanet.org/ConferenceArchive/9 4 e642011ab54.

Scheldrup, M., 2014.Lilliputian Choice: Explaining Small State Foreign Policy Variation. Undergraduate Honors Thesis. Paper 191, available at http://scholar.colorado.edu/honr_theses.

Šabič, Z., 2002. Small States Aspiring for NATO Membership: Some Factors Influencing the Accession Process.In: Buchowski, C., Šabič, Z., eds. Small States in the Post - Cold World, Slovenia and NATO Enlargement. London: Praeger: 1-24.

Thorhallsson, B., 2011. The Icelandic Economic Collapse: Incompetence or the Small Size? Reykjavik, Iceland: Faculty of Political Science. School of Social Science, University of Iceland.15 May 2011, available at: http://uni.hi.is.

Thorhallsson, B., Wivel, A., 2006. Small States in the European Union: What Do We Know and What Would We Like to Know?, Cambridge Review of International Affairs, 19(4): 651-668.

Vilpišauskas, R., 2011. National Preferences and Bargaining of the New 
Member States Since the Enlargement of the EU: The Baltic States Still Policy Takers? Lithuanian Foreign Policy Review, 25:9-32.

Vital, D., 1967. The Inequality of States: A Study of the Small Power in International Relations. Oxford: Clarendon Press. http://epp. eurostat.ec.europa.eu/tgm/table.do? tab=table\&init= 1 \&lang vage $=e n \& p c o d e=t p s 00001$ \&plugin=1 (accessed 28 May 2014) http://ec.europa.eu/eurostat/statistics-explained/ index.php/ (accessed 29 September 2014) http://ec.europa.eu/eurostat/statistics-explained/index.php/ GDP_per_capita,_consumption_per_capita_and_price_level_ indices\#Further_Eurostat_information(accessed29September2014) http://data.worldbank.org/indicator/NY.GDP.MKTP.KD.ZG http://stats.oecd.org/Index.aspx?.DatasetCode=SNA_TABLEl

Đana Luša (dlusa.fpzg@gmail.com) was born on 16 June 1982 in Šibenik, Croatia. After completing basic and high school education in Šibenik, she enrolled at the Faculty of Political Science, University of Zagreb, where she graduated in 2004. She holds an MA and PhD degree in International Relations from the same University. From 2006 till 2011 she worked as a research fellow at the Faculty of Political Science, while she currently occupies the position of a senior research fellow. She teaches International Relations, Euro-Atlantic Integrations and Modern Diplomacy. She delivered papers at numerous national and international conferences which resulted with publishing in relevant scientific journals. She is the author of a book on Theories of International Relations and editor of a Yearbook. She speaks English, German and Italian. Her research interests are small states, theories of international relations and transatlantic integrations. 
Petar Kurečić (petar.kurecic@unin.hr) was born on 1 September 1977 in Zagreb, Croatia. After completing basic and high school education in Zagreb, he enrolled at the University of Zagreb, Faculty of Science, and graduated in geography. He also enrolled at the Faculty of Political Science at the same University, and graduated in political science. He holds an MSc and PhD degree in social sciences from the same University. From 2003 until 2013, he worked for the Social-democratic party of Croatia and for the Party's Parliamentary club. From 2009 until 2013, he lectured at the College of International Relations and Diplomacy, Zagreb. In 2012-2013, he was Representative at the City Assembly of Zagreb. In 2013 and 2014, he was Dean of the Zagreb School of Business. He holds a scientific title senior research fellow in political science and research fellow in geography. Since April 2014, he has been working as assistant Professor at the University North, Croatia. He is author of one scientific book and twenty-eight scientific papers (one CC paper). He has delivered fifteen presentations at scientific conferences. He speaks English and German. 